ISSN 1689-765X

\title{
Rationality and Methods of Research Into Consumer Market Behaviour
}

\section{JEL Classification Codes: $D 11$}

Keywords: constructivist and ecological rationality, formal rationality principle, maximizing family concept, perspective theory, cognitive model, imperfect knowledge model

\begin{abstract}
The issue of rationality of consumption and consumer behavior becomes more and more relevant in today's economy. The objective of this article is to analyze the rationality of consumer behaviors in the market from the point of view of various economic schools, using classical methods as well as the concept of ecological rationality which is more akin to an institutional approach. The article also addresses important, selected aspects concerning certain approaches and methods used in research on rationality of consumer behaviors in the market. Particular attention is paid to the problem of rationality in methodology of empirical studies. The analysis of selected research approaches (i.e. predictive and postdictive approach) to the problem of rational choice and consumer behavior, considered from the point of view of both those approaches, makes for a summingup of the article.
\end{abstract}

(C) Copyright Nicolaus Copernicus University Press

Date of Submission: August 31, 2011; date of acceptance: March 16, 2012

* Contact: e-mail: tomasz.zalega@wp.pl, Uniwersytet Warszawski, Wydział Zarządzania, Katedra Gospodarki Narodowej, Zakład Gospodarki Rynkowej, ul. Szturmowa 3, 02-678 Warszaa, Poland 


\section{INTRODUCTION}

The behaviors of consumers in the market reveal vast diversification. The entirety of such behaviors may be generally divided into rational and irrational ones. This study enquires into the essence and the scope of rationality in consumer behaviors, as well as into the characteristics of rational behavior.

In appraising rationality, it is extremely important to properly consider the appraisal criteria and measures. Accordingly, the article focuses upon analyzing the dispute about how natural human behaviors really are. In fact, the rationality of consumer behavior has been studied from a number of various perspectives, including such approaches as the ones proposed by Amitai Etzioni, Herbert Alexander Simon, Max Weber, Harvey Leibenstein or Gary Stanley Becker, Daniel Kahneman and Amos Tversky, as well as Roman Frydman and Michael D. Goldberg. This article analyzes two key attitudes taken in attempts at interpretation of the concept of rationality, namely that of constructivist, rationality positioned within the classical approach to the problem of rationality and ecological (environmental) rationality, more akin to an institutional approach. Rationality as a criterion of the empirical model's relevance in studies belonging to general economy and to the game theory is the subject of another brief analysis presented in this article. However, particular attention has been given to the problem of rationality in the methodology of empirical studies. An analysis of selected scholar approaches (namely, predictive and postdictive approach) concerning the issues of rational choice and consumer behavior, considered from the point of view of both those approaches, concludes the article as a sort of summing-up.

\section{THE NOTION OF RATIONALITY OF CONSUMER BEHAVIOR IN ECONOMIC THEORY}

The rationality of human behavior is often addressed in social sciences. The notion of rationality is interpreted in various ways, mainly because of its inherent ambiguities. Very broadly, rationality is balanced, well-advised and reasonable behavior, leading to effective action. Then, one might argue, rationality is one fundamental category related with decision-making. Of course, there may be various types of rationality. Scholar or scientific rationality is certainly different from practical rationality, the latter mainly consisting in adequate selection of means in order to achieve intended objectives. In this way, any approach producing an effective solution to a problem can be 
called rational, no matter whether others reckon it rational or irrational ${ }^{1}$. Therefore, a rational decision-maker should be a person only driven by logically reasoned arguments, based upon information collected, adhering to a stable hierarchy of values and ends, and capable of skillful processing of information in order to properly calculate costs against gains.

The rationality of actions taken by individuals involved in some sort of business (consumers included) is an assumption found at the basis of the mainstream economy. In the theory of economy, speaking most generally, rationality is identified with the principle of rational management. In either a household or a business operating in the market, any goals are aimed at and achieved in line with the principle of the largest effect or that of the smallest disbursement of means. The principle of the greatest effect assumes that the maximum degree of achievement of an objective is attained at the smallest cost or using the least means. According to the principle of the smallest effect, one should act so that the minimum amount of means are used to achieve a given degree of achievement of the goal.

Rationality in relation to consumer behaviors may be considered in the context of peculiar nature of their activities. Rational behavior may be described as inherently consistent way of behaving which enables a consumer to achieve the maximum satisfaction on consumption. One can say, therefore, that a consumer acts rationally when, at a given income at hand, he makes best attempts to purchase a quantity of goods that provide him with most satisfaction (good feeling). However, rational behavior does not mean that people are immune to making mistakes. This does not mean that they always behave egoistically, either. Furthermore, having perfect information is not required for such behavior. On the other hand, there are often such factors as the force of habit or addiction that play an important role among limitations, physical or mental, of action. Psychological habits may complicate the process of choosing and lead to mistakes, but they do not stop people from behaving rationally. What we call rational behavior, in fact only

\footnotetext{
${ }^{1}$ Characteristics of irrational behavior include inherent inconsistence. It is in contradiction to a consumer's best interests. Irrationality means that a consumer has some needs or assumes some attitudes against evidences that prove them harmful and wrong. Indeed, it is irrationality understood this way that makes a reverse of rational behavior of consumers, rather than their non-rational behaviors which have been regarded by a number of economists as a sort of attitude that in fact supplements rationality. One could say, then, that we have to deal with irrational behavior in cases where consumers:

- have no clearly defined preferences and in effect they cannot put all the combinations of goods they consume in a clean-cut order,

- experience problems with identifying their own needs,

- cannot make inherently consistent choices in order to maximize the usefulness (satisfaction) derived from consumption, which in turn means breaching the assumption about completeness of preferences.
} 
relates to an individual, rather than to any external observers or social critic. Therefore, due to differences concerning the processes of judgments and evaluations, what seems rational to one man need not be regarded so by another. Moreover, one should remember that rationality actually relates to choices or decisions made by an individual, rather than to their effects (consequences).

Rational behavior is based upon three fundamental assumptions, according to which the consumer (Zalega 2007, p. 19):

- has some particular preferences he is able to describe;

- is willing to set all the needs he experiences in an inherently consistent order, ranking them from the most desired to the least intense;

- makes inherently consistent choices in order to maximize his satisfaction. A prominent representative of classical economy, Adam Smith, believed that " $[\ldots]$ every man makes permanent endeavors to find the most advantageous use for the capital he has at hand. He is driven, of course, by pursuit of his own benefits, rather than that of the society (Smith 1954, pp. 42-43). On the other hand, an English philosopher, political writer and economist John Stuart Mill argued in one of his methodological essays, as he defined political economy, that the economy considers man as creature only involved in attaining and consuming wealth and also as one which, out of necessity stemming from his very nature, must prioritize a larger over a smaller amount of goods (Mill 1962, p. 634). The above-quoted arguments of representatives of classical economy and the views they reflect have been defined as the homo oeconomicus ${ }^{2}$ concept i.e. one of a man in a model business.

\footnotetext{
${ }^{2}$ Representatives of classical economy did neither use the Latin term homo oeconomicus nor its English equivalent economic man. The Latin version, describing a concept of behavior of a model business was first applied by an Italian economist Vilfredo Federico Damaso Pareto, while the English one found its first application in writings of John Kells Ingram. According to John Stuart Mill, the concept of homo oeconomicus is just a theoretical construction that doesn't really describe any actual man, however it is useful in analyses of social economy. There are two key elements that should be distinguished in the homo oeconomicus concept: the formal one which defines the way in which rational man behaves and the material one which defines that man's structure of motivations i.e. indicates which impulse becomes decisive in his actions. The formal element in the homo oeconomicus concept is rationality in the instrumental sense. It means that as he chooses some kind of action from the pool of potential actions in given circumstances, a man considers gains and losses stemming from each choice and decides to choose the one that promises the most evident advantage of gains over losses. In other words, while deciding about prioritizing any particular action over other actions possible in a given situation, a man chooses the one which enables him to achieve his goals at as low cost as possible. Rationality in the instrumental sense is a formal element, because one can be rational in this very meaning, no matter toward what one strives. The material element in the homo oeconomicus concept is egoism. This means that a man aims at multiplying his own good. He derives no satisfaction, then, from the fact that others enjoy a given good, but at the same time he gains no satisfaction from other people's misery. Depending on the kind of goods a rational man cares for, both a strong and a weak version of the
} 
According to prominent representatives of classical economy, the aim of every action undertaken by a business is the achievement of one's own benefit, as well as the pursuit to achieve a goal set for oneself, as far as possible. It should be noted here that modern economists indicate a potential to distinguish between one's own benefit as a goal toward which a business aims and a pursuit toward the maximum achievement of a goal one sets as his objective. It is currently assumed that rational behavior maximizes any function of the goal (Hey 1993, p. 12), so a rationally behaving altruist is perfectly imaginable.

According to the neo-classic theory (quoting from what J.R. Hicks and R.G.D. Allen wrote, then supplemented by J. von Neuman and O. Morgenstern), the assumption on consumer rationality implies the way of behaving consisting in making choices in consistence with a pool of preferences set in a clear order, with respect to which it is assumed they are entirely transitive and occur under conditions of perfect information and zero costs of information (Blaug 1995, p. 335).

There is an issue related with rational behavior of a consumer - namely that of rationality in the area of consumption. One should point out here that literature of the subject lacks an unambiguous definition of rationality of consumption. This sort of rationality may be considered both in the context of the influence consumption exerts upon human development and in that of its impact upon socio-economic development.

Consumers' decisions are usually made over an ultra-short period (also called market period) and in short-term perspective, which results, to a certain degree, in limitation of rationality of consumers' behaviors. This is so, because in the process of decision-making a consumer does not takes the entire pool of determinants into account, such as the asymmetry of information, an ever-growing strength of the media or prompt changes in the supply of consumer goods and services available in the market, which determine an evaluation of rational choice. Accordingly, a consumer in fact only considers a short period and undertakes actions which are only rational from the point of view of subjective way of thinking, planning or the way in which the needs and values experienced are satisfied. However, considering that such actions undertaken by the consumer do not really lead to the achievement of the goals set or help accomplish them only partially, their consequences may well occur disadvantageous over a long-term perspective. According to A. Aldridge (2006:19), consumers as rational players are usually the best advocates of their interests, so they benefit from having the 
maximum choice possible and access to objective information on which they can base their choices.

Rationality as related to consumer behaviors was described in literature in a very clever way by J. O'Shaughenessy. According to that author, the degree of rationality in consumers' decisions largely depends upon the following factors (O'Shaughenessy 1994, pp. 55-56):

- rationality of the underlying need as such,

- whether the pool of products or brands considered includes the customer's best purchase,

- whether the customer properly discerns significant facts concerning the possibilities to choose from,

- a degree of rationality of information processed by the consumer.

Rationality with respect to consumer behaviors is also explained by the notion of usefulness. Usefulness is a psychological category which corresponds to notions such as satisfaction, contentment or pleasure. A degree of contentment, of satisfaction, as a measure of rationality of consumer behaviors is strictly related to features of rational behaviors, including purposefulness of action and calculation. One can argue, therefore, that purposefulness and awareness of action, making conscious use of knowledge a consumer has got, proper consideration for both external conditions and internal situation, referring to a system of values and making inherently consistent choices - such as make the consumer satisfied - describe that consumer's rational behavior, although the rationality is limited and only relates to decisions made over a short period. With that point taken into account, it may be said that the concepts of consumer behavior found in literature are based upon three basic assumptions:

- consumers don't perceive the principles of economic rationality as it is commonly understood;

- consumers don't make choices in casual ways and their behaviors cannot be described adequately using stochastic models;

- consumer behaviors are a result of needs, both innate and acquired, and consist in a complex combination of conscious as well as unconscious processes and mental as well as emotional factors.

It seems worthwhile to refer here to the criteria for evaluations of consumer behaviors. In this peculiar area of human activities, the degree of rationality cannot be expressed with just a single measure. Due to the complex nature of the notion of rationality, to presence of many criteria for evaluations and to difficulties in constructing adequate measures, evaluations of consumer behaviors are relative. In any specific study, one has to solve a number of concept- and method-related problems every time in order to properly set directions for analyses from which evaluation criteria and rationality measures are derived. 
According to J. Topolski, all consumers' actions can be arranged along a line between two extreme points. One point denotes a completely rational and thereby the most logical action, i.e. one taking the shortest route to the pursued goal while fully and adequately allowing for the existing circumstances, and the other stands for an irrational action (Topolski 1981). Rational actions occurring between these two extremes can be termed "subjectively" rational (Łukaszewicz 2001, p. 101).

From the economic point of view, rationality of consumers is derived from the principle of maximizing consumption with a given amount of resources or from the minimization of financial outlays necessary to achieve the target level of consumption. This is, then, an activity of a household which manages its resources so as to meet as soundly and completely as possible individual needs of its members and the needs it has as the whole entity, with a given level of income. The principle of rationality, instead, consisting in minimizing financial outlays, is often reduced to tactical behavior of households in a pursuit of meeting a given need. This relates to purchase of substitutes which are cheaper, if also inferior in terms of quality, or to increase a self-service way of supplying the household. Such behaviors succeed in reducing some expenses and the money saved may be allocated to purchasing other goods or services. It should be remembered, however, that there are also a number of other determinants, apart from income, which influence a level of rationality in the way households behave, including a place they live in, an offer they get on the supply side, a level of education, and so on.

Most generally speaking, rationality of consumption, in a similar way, as rationality of any other process, may actually be defined as purposeful activity aiming at the achievement of a specific intended goal in a manner improved over the previously applied one. However, one should observe that such an approach to the issue of rationality of consumption requires clear definition of the criteria it is based upon (Zalega 2008, p. 127). There may be two principal views distinguished as regards the initial criteria of the notion of "rationality of consumption". According to many economists, it is the system of a consumer's individual preferences which is assumed to be the basic criterion of rationality. It is assumed, therefore, that due to consumers making their choices of goods and services in line with their likings and in a manner corresponding to their interests, these preferences are rational. Potential social losses, if any, such as wasted consumption, are regarded in that context as a stimulator of economic growth. This opinion is opposed by another one, which assumes preferences of the society as the whole, appropriately synchronized with individual preferences, as the starting point for rational consumption. 
The principle of rationality of consumption may be considered both in relation to a micro-scale and to that of the society as the whole. Accordingly, rationality with respect to consumption-related behaviors and to consumption on a micro-scale is only of relative nature. Rational decisions are founded upon as complete information as is available under given circumstances, accumulated knowledge and significant criteria of evaluation. Rationality on a micro-scale relates, then, to specific "persons" or entities of consumption. Along with objective variables influencing the nature of decisions made by these persons, they are also influenced to a substantial degree by subjective factors. On a macro-scale, instead, rationality of consumption is evaluated from the point of view of economy and from that of the entire society. In other words, rationality on a macro-scale is really a pursuit after collective rationality in the area of shaping the structure of consumption and after minimizing or even eliminating losses in consumption that are regarded socially detrimental (Altkorn, Kramer 1998, p. 208). It can be concluded, then, that rational consumption is one which is not only harmless to an individual, but also fosters the development of their personality and shapes a desired model of social relations. It should be added that on a macro-social scale rationality is promoted, among other things, by: adequate supply of the market, reliable information on goods and services, appropriate alignment of the offer to needs of particular groups of households, propagation of the principles of rational feeding, sound management of households as well as town-planning facilities and modifications, transport improvements and so on (Kieżel 2004, pp. 29-31; Zalega 2008, p. 127).

Tadeusz Marian Kotarbiński, a Polish philosopher, the proposer of a current called reism and one of the pioneers and co-authors of general theory of efficient human action known as praxeology, introduced two crucial kinds of rationality: real rationality and methodological rationality, which were subsequently popularized among economists by Oskar Lange. We have to deal with the former one where the selection of measures corresponds to some real, objectively existing institution i.e. actually existing facts, laws and relations. With the latter one, instead, we have to deal where the selection of measures is correct in the light of the knowledge a decision-maker has collected. Real (or factual) rationality takes place in specific particular circumstances (political, economic, cultural, organizational, geographic etc.) which are subject to some changes over time. Choices are made in the conditions of incomplete information. Rationality is based upon knowledge, it occurs here and now (Zacher 2000, p. 21). In other words, methodological rationality causes the behavior to be adapted to the possessed knowledge, whereas real rationality subordinates behavior to real knowledge (Kotarbiński 1958, p. 138). However, because of the various aspects of "rationality", the literature distinguishes ontological, epistemological and praxeological rationality 
(Jakubowski 1998, pp. 91-103); logical, scientistic and technological rationality (Skarga 1987, pp. 87-117); and ontological, epistemological, methodological, axiological and praxeological rationality (Kleszcz 1994, pp. 347361),

The choices made by an individual are also determined by that person's system of values. Authors of many studies concerning the issue of rationality of human actions emphasize the importance of such features as active approach toward collection of information, planning skills, calculation, awareness of the need of effective action, and so on.

The theories describing the way consumers behave also explain the essence of rationality of their behaviors. This type of studies and theoretical reflections in this field were pioneered by an Italian economist and representative of the Lausanne school Vilfredo Federico Damaso Pareto. Before him, this problem had been considered by economists originating from subjective-marginalistic current in economy, such as William Stanley Jevons, Leon Walras, Francis Ysidro Edgeworth and Irving Fisher. Then, after V.F.D. Pareto, the problem of rationality was addressed in studies authored by, among others, John Richard Hicks, Eugeniusz Slutsky, Roy George Douglas Allen, H. Wold, J. von Neuman and O. Morgenstern, G. Katona, as well as D. Kahneman and A Tversky (Zalega 2012, p. 35).

In his studies on consumer market behavior, G. Katona questions the rigidity and exclusivity of the homo oeconomicus model with a utilitymaximizing consumer. He points to the weight of factors and circumstances determining one's choices and decisions, as neither rational calculations nor irrational behavior can explain the complex reality. This fact makes G. Katona state that the rationality of consumer behavior is a characteristic of reasonable and well-thought-out choices where the consumer considers various options and their consequences before they are taken, discusses the intended purchase with other family members or friends, as well as seeking more complete market information. Therefore, according to Katona, only some aspects of consumer behavior have certain rational characteristics.

Then, according to Max Weber, the author of the formal principle of rationality, the narrowly understood of "rationality" means rationality manifesting itself through the choice of the most effective measure to achieve previously determined objectives (Weber 2002). This proves that rationality is a feature of purposeful action which reflects relationships between measures used and the goal to be achieved and which actually occurs in an action where we have to deal with a proper choice of measures to the achievement of that goal. Moreover, M. Weber believed in his theory that rational action is one of possible ways of behaving, along with irrational, adaptive, traditional and other behaviors (Semkow 1974, p. 95). One also has to remember about the position taken by Ludwig Heinrich Edler von Mises, 
a prominent representative of the Austrian school in economy which remains in plain opposition to the previously mentioned one. Namely, L.H.E. Mises (2007) argued in his theory that rationality, rather than in irrationality, indeed has its reverse in reactive action i.e. one that is not determined by human will.

\section{THE DISPUTE OVER RATIONAL CONSUMER BEHAVIOR - IS IT INHERENT?}

The problem of rationality of human actions manifests itself both in ontological assumptions concerning, on the one hand, the very essence of nature of an acting individual and, on the other hand, epistemological assumptions regarding theoretical and methodological issues. A dispute over consumer rationality has really been, from the very outset, a philosophical and moral dispute over human nature. An argument according to which the man is, by nature, a rational creature, reemerges since the beginning of considerations regarding economy. Over time, it assumed various forms, including the assumptions about egoistic human nature only pursuing its own interests, as found in Bernard de Mandeville's The Fable of the Bees or in well-known works by Adam Smith. It also appeared in the concepts by John Stuart Mill and Jeremy Bentham in the context of utilitarianism and hedonism (Sagan 2008, p. 227).

The neo-classic revolution brought along the concept of an economic man in the writings of Alfred Marshall and then took yet another, modified form of rational-consistent economic man in the works by J.R. Hicks and R.G.D. Allen.

The way consumers behave, manifesting itself as gradable, inherent and natural characteristics of how consumers act has been severely criticized by Amitai Etzioni $^{3}$ (his real name was Werner Falk) and John Ruskin (Zalega 2009a, p. 64). It is A. Etzioni's proposal that seems especially interesting, as he emphasized that rationality as such is not a "natural" tendency in any

\footnotetext{
${ }^{3}$ In 1968, Amitai Etzioni introduced the notion of a postmodernist society to sociological literature. He came to a conclusion that modernism does not end because of some turning point but as a result of transformation, and that the post-modernist stage evolves following technological changes and macro trends, which are global trends driven by marked tendencies in the world economy. He has also developed the notion of homo sociologicus for a human led by normative and affective values, being the opposite of homo oeconomicus. This type of a person follows the heart and not the mind and pursues values rather than economic results (profits). Naturally, the line between homo sociologicus and homo oeconomicus is quite fluid. Yet, both the concepts contain important elements that enable the creation of the socioeconomic man whose behaviors are reflected in the reality. More on this subject can be found in: Etzioni, Lawrence (1991).
} 
consumer's behavior. Instead, the Author puts forward a very logical thesis that rational actions require some cognitive efforts related to education, socialization and accumulation of intellectual capital in social micro-structures, as well as development efforts involving continuous investment and the fostering of one's ability to make rational decisions; without these efforts the previously rational behavior would return to its initial entropic state (Etzioni, 1986, pp. 32-36). The conclusion from the above-mentioned reasoning is that rationality should be seen as a variable which is closely correlated with cognitive abilities, effort, costs of information, factors determining the action and conditions prevalent in one's environment. A similar position is assumed by Georgescu-Roegen who argues that consumer's behavior is characterized by a significant promiscuity of choice, emotionality, inconsistence, lack of calculation, susceptibility to inherent conflicts, resistance to arguments and propensity to group thinking. Therefore, the Author proves that it is nonrationality, described as "entropic" condition which is "natural" state for a consumer. A. Etzioni came up with an audacious concept that rationality or rational actions are essentially anti-entropic. They assume taking some cognitive effort related with seeking and processing information as well as development-related effort in constant investing in and maintaining one's ability to make rational decisions, without which previously rational behaviors tend to corrupt into their initial entropic state (Etzioni 1986, pp. 17-18). Accordingly, for A. Etzioni the fundamental question is not whether a consumer is rational or not. Instead, it is in which conditions of the environment they tend to be rational (Sagan 2008, p. 227).

The consideration of psychological, cultural, institutional and microstructural factors has contributed to a more realistic approach to rationality in consumer behaviors. In his limited rationality concept formulated in 1957, an American economic and sociologist Herbert Alexander Simon takes the perspective of cognitive psychology, thus rejecting the principle of maximization of benefits typical of orthodox economy. The Author assumes in this theory that a consumer, as he or she makes decisions regarding consumption, only tends to satisfy a certain level of demands - understood as his ambitions, needs and future-related plans, rather than to seek really the best alternatives. According to H.A. Simon, in his actions a consumer aims at meeting his needs in as satisfactory way as practicable - just that and nothing more. The lack of pursuit to maximize benefits results, on the one hand, from objective circumstances i.e. from the complexity of the market in which situations change and cannot be foreseen on a long-term basis and market-related information is always limited. On the other hand, it results from internal limitations, including a limited possibility to convert information into decisions, actions undertaken under influence of an impulse, the lack of propensity to risk as well as habit-determined behaviors. One can say, therefore, 
that this concept considers the way a consumer acts in a more realistic manner as it takes such factors as incomplete information and cognitive limitations into account. In his concept of limited rationality H.A. Simon pointed out subjective and inter-subjective approach to rationality, adding that it has procedural nature due to the way decision-making processes unfold and that it also becomes restricted due to specific conditions of knowledge collected and to uncertainty involved (Simon 1976, p. 147). It should be observed here that the theory of limited rationality indicates two significant aspects: firstly, not all consumers are interested in achieving the optimum results, because they have only limited cognitive abilities which hinder them from proper considering of all rational possibilities. Secondly, as consumers make consumption-related decisions, they are driven by the necessity to meet their needs, but they also consider social circumstances. This means that, according to the concept of procedural rationality, the very way of behaving in line with some specific rules (which makes a fundament for evaluating of how rationally one manages his income) is really more important than the result of such management. Therefore, it should be assumed that rational management of financial resources in a household is preceded by an analysis of goals and of means necessary to meet them. Summing up, it can be said that this concept is more realistic in presenting the functioning of consumers in the world of imperfect information and cognitive limitations.

H.A. Simon's concept of limited rationality was then extended in the works of D. Kahneman and A. Tversky $(1973 ; 1979)$, the proponents of prospect theory recognized as the most prominent representatives of experimental economy and behavioral economy, of G.A. Akerlof (1984), the precursor of studies on information asymmetry, and of representatives of neoinstitutionalism D.C. North and O.E. Williamson (1985), the latter being the creator of the behavioral uncertainty hypothesis.

Also Harvey Leibenstein, in his concept of selective rationality, proved that consumer is equipped with a certain set of personality-related properties which determine the degree to which a consumer is aware of limitations concerning the calculation involved in the pursuit of and the achievement of particular goals. On the other hand, however, we observe various levels of pressure, either internal or external, which impose either a higher or lower level of calculation behind the actions which are undertaken. Therefore, a consumer's behavior results from a choice of an appropriate combination between the level of awareness of limitations and that of pressure. It may be said, then, that consumer rationality stems from his maximizing strategies of choice of a level of calculative rationality, depending on the pressure of the environment (Sagan 2008, p. 228; Zalega 2008, p. 220). The concept of selective rationality drives consumer behavior beyond the homo oeconomicus scheme, however it provides no tools to predict consumer behavior. 
The notion of duality of the structure of rational behaviors, as observed by $\mathrm{H}$. Leibenstein, was then developed by representatives of radical and critical current in economy, including, in particular, A. Etzioni and R. Lutz. These Authors derive the way a consumer's preferences are shaped from the so-called dual self concept (which assumes that first- and second-rank preferences are shaped in effect). A. Etzioni and R. Lutz argue that classical economic concepts only focus upon the structure of first-rank preferences, while totally ignoring second-rank ones which include self-consciousness of individuals and their ability to reflect - in many cases morally - over the structure of choices made. This, in effect, leads to the concept of the socalled restrained rationality, basing upon dual system of judgment, metarankings and meta-functions of utility (Etzioni 1988, p. 47; Sagan 2008, p. 229). Such a type of behavior has often been described in literature as reasonable behavior.

An American economist and historian Douglas Cecil North (1992) focused upon identification and description of factors which seriously disturb a consumer's rational choice. He mentioned the following as the most important determinants acting as barriers to rational choice: problems in measuring the value of goods, behaviors of parties to the exchange, anonymity of bodies operating in the market, a level of effectiveness with which law is enforced as well as nature of inter-personal relations. Moreover, D. North (1992) pointed out the role played by institutions (regarding them as the society's game rules) in making rational choices, underlining at the same time that they form an instrument used by consumers in order to maximize benefits that are achieved in the processes of enlarging individual wealth. According to him, behavior of individuals is determined not only by exogenous (i.e. imposed from the outside) norms, but also by a degree of their internationalization by particular individuals. Accordingly, the higher the level of conformity of behaviors to norms, the more serious disturbance is observed in the process of market exchange, which proves that institutional solutions significantly influence decisions made by individuals. In the light of earlier remarks, the role institutions play is that of regulating interpersonal relations. Although they are not always effective in it, they nevertheless are indispensable, particularly in the context of what Robert Emerson Lucas (1972), the author of the theory of market balance in conditions of rational expectations and incomplete information, said: in the case of an uncertainty, economic thinking is of no great value. Another factor, just as important in D. North's proposal which determines rationality of actions undertaken, is that of transaction costs. Along with market-related costs of carrying out the transactions, they also include costs of detecting and processing of information as well as costs resulting from inconsistency of norms with subjective way of perceiving the reality (Szumilak 2008, p. 250). 
The issue of rationality of consumer behavior was also addressed in the concept of maximizing family, proposed by an American economist Gary Stanley Becker. The Author argues in this theory that a consumer being a family member is fully aware of the necessity to choose between his own interest and that of his family as well as of relations existing between his own actions and those undertaken by others. As a result, a consumer often involves in altruistic, spontaneous and also rational actions, undertaken in his well-perceived own interest but at the same time contributing to the achievement of his family's goals (Becker 1990, p. 11). Family members, also, make their decisions driven by reflection rather than emotions, so that their actions may be described using the analysis of maximization of utility of resources (capital, knowledge or work) as well as of broadly-understood consumption-related choices.

According to G.S. Becker, the market is going to operate "as if it was rational" not only when consumers are rational, but also when they are inert, impulsive or non-rational in any other way. According to what he argued, rationality of the market can be reconciled with irrationality of the consumer (Becker 1990, p. 279). Moreover, G.S. Becker disagreed with the statement that assumed the attribution of universal rationality to businesses only on the basis of observation of market rationality. Also, he found it wrong to argue that the market cannot operate in a rational way due to the presence of irrationally operating businesses therein. G.S. Becker was convinced that irrational behavior of businesses may take place along and in parallel to rationality of the market as the whole and he furthermore maintained that individual businesses, no matter the actual nature of how they do (i.e. whether they act rationally or irrationally) are even forced by their pools of possibilities, either productive or consumptive, to operate in such a manner which in consequence enables the market to work in rational way.

Another theory addressing the issue of consumer rationality is a descriptive theory (building on J. von Neuman's and O. Morgenstern's normative, classical theory of expected utility maximization) known as prospect theory, which was proposed in 1979 by two Israeli psychologists Daniel Kahneman and Amos Tversky.

Rather than completely rejecting the rationality assumption and seeking a brand-new approach, both researchers used it as a point of departure and investigated the deviations from it, treating them as anomalies in rationality viewed as a kind of model behavior. In this way, they tried to design economic models of human behavior that, drawing heavily on the achievements of psychology, would be more realistic and would describe the limitations and flaws in human rationality. The prospect theory explains how people make decisions under conditions of risk, takes into account empirical data concerning decision-making under conditions of uncertainty and also clari- 
fies why and how people's behavior deviates from the model of expected utility. The prospect theory has been regarded as one of ground-breaking theories in behavioral economy. This theory is in opposition to the theory of expected utility ${ }^{4}$, prevailing in the mainstream economy, and to the assumption on the aversion to risk. The prospect theory focuses upon two important issues, namely on how individuals develop their relationship toward values and how they evaluate and treat opportunities. In other words, this model, also known in economic literature as endogenous prospect theory, is founded upon the assumption that the preferences of an individual at any given moment reveal some specific features, specified in qualitative terms. That ranking of alternatives largely depends on the outcomes of decisions it expects, regarding the allocation of productive factors (resources) and in particular on its expectations regarding future gains and the scale of potential losses. The model also assumes that aversion to loss is the stronger, the greater the anticipated loss (Zalega 2012, pp. 39-40).

The prospect theory assumes that an individual's well-being depends on the modification of the target variable which is described in terms of gains or losses against some reference level, rather than an absolute, final value. Moreover, the utility function based upon prospect theory has a different functional form than its traditional equivalents implying aversion to risk (Tversky and Kahneman 1992, p. 318).

It is worth adding at this point that using their research results D. Kahneman and A. Tversky (1979) have demonstrated that not only is the utility function non-linear, but also that it is likely to be more curved for losses than for profits. This finding made behavioral economists introduce a modified version of Kahneman and Tversky's utility function to account for a positive correlation between increasing aversion to loss and the value at stake. A characteristic of the utility function called endogenous aversion to loss

${ }^{4}$ The theory of expected utility regards modeling of a consumer as he makes choice not between events that are certain, but lotteries formalized using random variables the potential outcomes of which belong to the $S$ pool of certain available alternatives. There may be any elements of the $S$ pool of available alternatives; they may describe, for example, streams of consumption over time. The only significant limitation is that the elements of the $S$ pool were non-random. The theory of expected utility imposes one very peculiar condition upon the form the utility function assumes. The theory of utility, where $U(x)$ is the function of utility with the domain within the S pool, then any function $g(U(x))$, where: $g(t)$ is an increasing function, leads to the same conclusions. In the theory of expected utility, the function of expected utility $V(p)$ is related with the function of utility $U(x)$, which may be recorded using the following formula: $V(p)=\int V(x) d F p(x)$, where: $F p(x)$ - cumulative distribution function of the random variable $p$.

Considering that the value expected is a linear operator, the theory of expected utility leads to the same conclusions for the function of utility $U(x)$ and $g(U(x))$ only where $g(t)$ is an increasing linear function, i.e. $g(t)=a t+b$, where: $\mathrm{a}>0$. 
makes it possible for economists to model limitations to speculation and thereby present well-defined balance derived from prospect theory (Tversky, Kahneman 1992, pp. 299-301).

As mentioned before, there is some simple assumption made in this theory, which implies that any individual chooses a certain reference point and thereafter defines potential consequences of choices it makes as gains or losses with respect to such a benchmark. It should be observed at that point that it is critical to define a point of reference, since each individual evaluates gains and losses in a different way. It is quite natural that a loss is experienced by an individual as a stronger emotional impulse than gains in the same amount. One can say, therefore, that definition, by an individual, of perspective with respect to which choices made thereby will be assessed, has crucial importance, especially as serious expenses are borne, e.g. in the form of investments (Tyszka, Zaleśkiewicz 2001, p. 109).

The prospect theory throws a new light upon theories which attempt to describe the way consumers behave in the area of making consumptionrelated decisions and factors involved in the choice of consumption level under the influence of changes in income. This theory proves that as their income decreases, consumers take a risk (they maintain their most recent level of consumption in order to protect themselves from or postpone the experience of painful loss), while in the case of their income increasing, consumers avoid risk, so their consumption is going to grow up slower than their income, because gradual improvement entails long-term course along the path of profit at a level close to the benchmark. The same phenomenon manages to minimize the risk of having to radically reduce consumption as income decreases. This strategy also allows time needed to change consumption-related habits.

In my opinion, A. Tversky and D. Kahneman have undoubtedly proved with their research that consumers making uncertain choices use a limited number of heuristic rules which do not require complex cognitive operations for assessing probabilities and choosing the optimal option. They have also demonstrated that using heuristics in a decision-making process very frequently leads to mistakes that are not only serious, but also systematic. An alternative solution to expected utility theory they have presented is called axiomatic prospect theory. R.H. Thaler and H.M. Shefrin (1988) who were drawing on A. Tversky and D. Kahneman's research obtained in mid-1980s many interesting results within consumer choice theory, formulating for instance the behavioral life cycle theory ${ }^{5}$.

Another theory addressing the rationality of consumer choices is the cognitive model, also known as an extended model of problem solving. The

${ }^{5}$ More infomation on the behavioral life-cycle theory can be found in: Zalega (2012, pp. 215-218). 
model in question is in opposition to the primate of behaviors, which is called behaviorism and says that it is neither a thought nor emotions that initiate action, because undertaking of an action is explained by circumstances that are present in the environment and influence consumers. The cognitive model proposes that, indeed, both thoughts and emotions may directly contribute to changes in the way a consumer acts. Therefore, decisions made by consumers are based on their beliefs concerning the pool of possible, available choices which make the object of studies and comparisons. Moreover, the theory of cognitivism explicitly emphasizes the existence of rational reasons for consumers making their decisions. According to one of the ideas within that theory, experience may be interpreted and used to change attitudes and knowledge that determine the consumers' behaviors. From the perspective of cognitivism, consumer behavior may undergo constant changes through communication which modifies attitude and knowledge.

In turn, the imperfect knowledge model which Roman Frydman and Michael D. Goldberg formulated in 2005 assumes that models in contemporary economy generally consist of representations of individual preferences, limitations and forecasts of future events that may potentially influence one's welfare. Moreover, this model is consistent with an assumption implying that all market players only act in the pursuit of their own interest. This means that as an economic analysis focuses upon the interest of an individual, it is likely to overlook some significant issue. Namely, even if acting only in one's own interest was indeed so common, such an assumption would not enable an observer to create any entirely determined model of such behavior nor its implication for total outcomes and effects of economic policies. Individual decisions largely depend upon future market conditions. Therefore, these effects are not only a consequence of actions of many individuals, because they are also determined by the future economic policies, political and institutional changes. As John Kay puts it, even if economists were capable of attributing clearly defined objectives to a consumer, they would not be able to evaluate his or her rationality. According to R. Frydman and M.D. Goldberg (2007, pp. 9-10), one result of it is that even if individuals were assumed to act only in their self-interest, their behavior would still equally depend on the social context and personal motivations. Therefore, the imperfect knowledge model assumes that as economists are incapable of finding out whether or not someone's behavior is rational, they cannot determine whether the person's attempts to achieve goals are reasonable, either. In my opinion, the imperfect knowledge model as developed by R. Frydram and M. Goldberg creates models by linking aggregate effects to individual behavior. As all scientific theories, the imperfect knowledge model must assume that purposeful action has some regularities, although these may de- 
pend on the context. However, the model admits a possibility that the regularities, i.e. the ways in which market players make and change their decisions, can be formalized by means of qualitative conditions. As I view it, the conditions only partially predetermine the anticipated structural changes, unlike the case of the standard model and the behavioral model. This makes me conclude that R. Frydram's and D. Goldberg's model of imperfect knowledge solve the epistemological problem that the determined economic models built on micro bases could not disentangle.

\section{CONSTRUCTIVIST AND ECOLOGICAL RATIONALITY}

It may be concluded from this concise review of opinions that the notion of rationality plays the role of a construction created by a researcher and used as an element of a notional network enabling one to better understand the phenomena of consumer behavior as well as an element for building a theoretical model. From the point of view of the function of that notion in the structure of the nomological network of the consumer behavior theoretical model, there are two notions of rationality that may be distinguished: the constructivist and the ecological one (Smith 2003, p. 465).

Classical inquires into the problem of consumer rationality clearly belong to the current which Friedrich August von Hayek after Descartes, Francis Bacon and Thomas Hobbes described as constructivist rationality. In this perspective, the criterion of rationality is related with creation of social order and of social institutions. This way, it explains the emergence of social institutions as effects of conscious and rational decision-making processes. This assumption is found at the basis of most predictive decision-making models which are related to the creation of hypotheses tested in the area of mental experiments in economic psychology.

Another perspective, closer to institutional approach - is related with the concept of ecological rationality, in which rationality is a function of the structure of an individual's environment.

Ecological rationality is understood as conformity of a chosen heuristic with the structure of the environment. This type of rationality is an effect of biological and cultural processes of evolution leading to the emergence of rules of conduct and moral norms and is based upon experience and common knowledge of consumers, who are, in a very natural way, not clever enough to be able to consciously apply the tools of procedural rationality in the process of their decision-making. 
Therefore, the true nature of models of consumer behavior built upon the assumptions of ecological rationality is retrodictive so they relate to rationality of reconstruction of social order and social institution emerging and evolving over time.

\section{RATIONALITY AS AN ACCURACY CRITERION OF THE EMPIRICAL MODEL}

The fundamental statement which stems from the inquiry made so far proves that rationality, rather than being a feature of the consumer, is a feature of the researcher's model. A consumer's behavior is rational if the researcher can provide an explanation or prediction of the consumer's behavior basing upon the theoretical model he adopted.

The assumption about rationality depends on whether a theory created on its basis is capable of explaining or predict particular behaviors of the consumer. According to Steven Shugan (2006, pp. 3-4), consumers seem to reveal a considerable degree of rationality in well-documented situations of choice, because we are equipped with accurate and well-developed models of their description. In other, less explored situations of choice consumers may seem irrational because the models we have so far simply cannot come up with an accurate prediction of the effects of their action.

In economic theory, this assumption is related with conditions sufficient for existence of an appropriate function of utility of the consumer. Mainstream economy defines consumer rationality in terms of maximization of the expected utility and a set of axioms sufficient for such a function to take place. In turn, game theory views rationality as choosing the optimum line of action with regard to a given matrix of payoffs and under the existing game rules. Accordingly, the foundations for evaluating the assumption about rationality is the criterion of predictive accuracy of the model a researcher applies, compared to prediction carried out without that model. It this approach it is assumed that rationality is a feature of the theoretical model adopted than an inherent property of the consumer. Consumers seem rational in situations in which our models are capable of explaining or predicting their behaviors. Therefore, the assumption about irrationality of consumers mainly emerges from the fact that no model was found to enable prediction or explanation of these behaviors. Irrationality of the consumer is thus just a faithful reflection of researcher's inefficacy (Shugan 2006, p. 7). 


\section{THE PROBLEM OF RATIONALITY AND METHODOLOGY OF EMPIRICAL STUDIES}

From the point of view of where rationality belongs in the nomological network, two types of approach may be distinguished, namely the constructivist one and the evolutional one.

In the classical approach, the inquiries into the problems concerning rationality of choice are mostly related with an experimental attitude. This really stems from the very nature of predictive models underlying the procedural rationality. Two peculiar characteristics of that approach are, firstly, that it attempts to come up with an accurate prediction of a phenomenon basing on a limited number of hypotheses (in line with the Ockham's principle, the simpler the model, the better it gets) and, secondly, that it pays particular attention to monitoring of the independent variables situated beyond the scheme of the experiment. This protects the researcher either from false positive or false negative results. In this area, we often have to deal with a phenomenon known as the asymmetry of underdefinition, which consists in the effects being underdefined by their reasons. Also, the impulses that precede given effects as their drivers are neither the only nor sufficient factors for their occurrence (Clelland 2002, p. 476). As a result, "the future is not entirely determined by the present". This problem explains the low predictive power of classical models of choice and preference based upon the theory of expected utility in consumer behaviors, tested under experimental conditions (Cohen, Dickens 2002, p. 336). It fact, it also explains, even if partially, the resulting conclusions about irrationality of behavior.

The examples of research approaches concerning the issue of rational choice and consumer behavior which are related to the predictive approach include experiments in behavioral economics referring to expected utility theory, experiments in evolutionary psychology, 'less-is-more effects', or finally analysis of recognition heuristics.

Postdictive analyses are more often applied in attempts to explain ecological rationality. This current includes historical analyses, diary panels and indeed a majority of attempts to understand preferences and choices of a consumer in survey-based studies. One characteristic of that approach is that it attempts to explain latent rules underlying and determining consumer choices using a considerable number of observable indicators of the choices. This approach is subject to a phenomenon described by David Kellogg Lewis $(1991$, p. 67) as asymmetry of over-determination, which consists in cognitive over-defining of the reasons by their observable effects. Therefore, in the case in question, observable effects outnumber the underlying driving factors (reasons). In consequence, "future is over-determined by the present". This effect explains an equivalent diagnostic accuracy and statistic 
significance of the large family of empirical models and verified hypotheses which may be just as well tailored to data and thus used to justify all the arguments and heuristics used by consumers in their decision-making process.

Among the best known research approaches dealing with the issue of rational choice and consumer behavior which are related to the postdictive approach, there are empirical analyses based on joint measurement theory, information processing models, McFadden's model, Fishbein and Ajzen's model of reasoned action, ethnographic decision-making models, as well as empirical analyses based on means-end chain theory.

\section{CONCLUSIONS}

In conclusion, of what has been proposed so far one should say that the issue of studies regarding the rationality of consumer behaviors is present within various currents of theoretical and methodological thought, differing in approaches to definition of the very notion of rationality as well as in methodological tradition in explaining consumer behaviors. Rationality of such behaviors is in fact a function of formal properties of theoretical concept and an effect of control, either experimental or statistical, of variables the researcher included in a given model. This is, therefore, the researcher's construct rather than any empirically observable feature of those under the study. The usefulness of such a construct mainly depend on whether models and theories built upon its basis enable us to explain or forecast consumer behaviors in a more accurate, precise and sound way.

\section{LITERATURE}

Akerlof G.A. (1984), An Economic Theorist's Book of Tales, Cambridge University Press, Cambridge.

Aldridge A. (2006), Konsumpcja, Wydawnictwo Sic!, Warszawa.

Altkorn J., Kramer T. (ed.) (1998), Leksykon marketingu, PWE, Warszawa.

Becker G.S. (1990), Ekonomiczna teoria zachowań ludzkich, PWN, Warszawa.

Blaug M. (1995), Metodologia ekonomii, PWN, Warszawa.

Clelland C.E. (2002), Methodological and Epistemic Differences between Historical Science and Experimental Science, „Philospophy of Science”, No 69.

Cohen J.L., Dickens W.T. (2002), A Foundation for Behavioral Economics, ,American Economics Review", No 92.

Etzioni A. (1986), Rationality is Anti-entropic, „Journal of Economic Psychology”, No. 7.

Etzioni A. (1988), The Moral Dimension. Toward a New Economics, Free Press. 
Etzioni A., Lawrence P.R. (ed.) (1991), Socio-economics. Toward and a New Synthesis, Armonk, New York.

Frydman R., Goldberg M.D. (2007), Imperfect Knowledge Economics: Exchange, Rates and Risk, Princeton University Press, Princeton-New Jersey.

Hey J.D. (1993), Is As Rationality Does, [in:] B. Gerrard (ed.), The Economics of Rationality, Routledge, London-New York.

Jakubowski J. (1998), Racjonalność a normatywność zachowań, Wydawnictwo Naukowe IF UAM, Poznań.

Kahneman D., Tversky A. (1973), On the psychology of prediction, "Psychological Review", No. 80.

Kahneman D., Tversky A. (1979), Prospect Theory: An Analysis of Decision under Risk, "Econometrica" No. 47.

Kahneman D., Tversky A. (1979), Prospect Theory: An Analysis of Decision under Risk, "Econometrica", Vol. 47, No. 2.

Kay J. (2004), Obliquity, "Financial Times", January 17.

Kieżel E. (ed.) (2010), Konsument i jego zachowania na rynku europejskim, PWE, Warszawa.

Kieżel E. (2004), Koncepcyjno-metodologiczne problemy badania racjonalności zachowań klientów, [in:] B. Gregor (ed.), Marketing - Handel - Konsument w globalnym społeczeństwie informacyjnym, Wydawnictwo Uniwersytetu Łódzkiego, Łódź.

Kleszcz R. (1994), O rozumie, racjonalizmie $i$ racjonalności, [in:] T. Buksiński (ed.), Filozofia $w$ dobie przemian, Wydawnictwo Naukowe IF UAM, Poznań.

Kotarbiński T. (1958), Traktat o dobrej robocie, Wrocław-Warszawa.

Leibenstein H. (1988), Poza schematem homo oeconomicus. Nowe podstawy mikroekonomii, PWN, Warszawa.

Leibenstein H., (1979a) A Branch of Economics is Missing: Micro-Mictro Theory, „Journal of Economics Literature”, June.

Leibenstein H., (1979b) X-Efficiency: from Conspect to Theory, „Challenge“, September-October.

Lewis D.K. (1991), Counterfactual Dependence and Time's Arrow, [in:] J. Jackson (ed.), Conditionals, Oxford University Press, Oxford.

Lucas R.E., (1972), Expectations and Neutrality of Money, "Journal of Economic Theory", No. 4.

Łukaszewicz A. (2001), Dylematy ekonomiczne przełomu stuleci, Key Text, Warszawa.

Mill J.S. (1962), System logiki dedukcyjnej i indukcyjnej, Vol. 2, PWN, Warszawa.

Mises J. (2007), Ludzkie działanie. Traktat o ekonomii, Instytut Ludwiga von Misesa, Warszawa.

North D. (1992), Institutions, Ideology and Economic Performance, "CATO Journal", Vol. 11, No 3.

O’Shaughnessy J. (1994), Dlaczego ludzie kupuja, PWE, Warszawa.

Sagan A. (2008), Racjonalność - właściwość konsumenta czy modelu badacza, [in:] Z. Kędzior, G. Maciejewski (ed.) Zachowania konsumentów - stagnacja czy zmiana, Wydawnictwo Akademii Ekonomicznej w Katowicach and CBiE, Katowice.

Semkow J. (1974), Spór o metodę, PWN, Warszawa. 
Simon H.A. (1976), Model of Discovery and Topic in the Methods of Science, D. Reidel Pub. Co., Dordrecht, Holland-Boston.

Sen A., (1977), Rational Fools: A Critique of Behavioral Foundation of Economic Theory, „Philosophy and Public Affirs”, No 6.

Shugan S. (2006), Are Consumers Rational? Experimental Evidence?, „Marketing Science", No 25.

Skarga B. (1987), Trzy idee racjonalności, [in:] B. Skarga (ed.), Przeszłość i interpretacje, $\mathrm{PWN}$, Warszawa.

Smith V.L. (2003), Constructivist and Ecological Rationality in Economics, „American Economic Review" June.

Smith A. (1954), Badania nad natura i przyczynami bogactwa narodów, Vol. I, PWN, Warszawa.

Szumlik J. (2008), Racjonalność zachowań konsumentów w aspekcie gospodarowania informacja, [in:] Z. Kędzior, G. Maciejewski (eds.) Zachowania konsumentów - stagnacja czy zmiana?, Centrum Badań i Ekspertyz AE w Katowicach, Katowice.

Thaler R.M., Shefrin H.M. (1988), The Behavioral Life-Cycle Hypothesis, "Economics Inquiry", Vol. 26, No. 4.

Topolski J. (1981), Dyrektywy działań ludzkich, [in:] B. Kamiński and A. Łukaszewicz (eds), Racjonalność gospodarowania w socjalizmie, PWN, Warszawa.

Tyszka T., Zaleśkiewicz T. (2001), Racjonalność decyzji. Pewność i ryzyko (Rationality of Decision-Making. Certainty and Risk), PWE, Warszawa.

Tversky A., Kahneman D. (1992), Advances in Prospect Theory: Cumulative Representation of Uncertainty, ,Journal of Rink and Uncertainty”, No 5.

Weber M. (2002), Gospodarka i społeczeństwo. Zarys socjologii rozumiejącej, PWN, Warszawa.

Williamson O.E. (1985), Reflections on the New Institutional Economics, "Journal of Industrial and Theoretical Economics", No. 141.

Zacher L. (2000) (ed.), Racjonalność myślenia, decydowania i działania, Wydawnictwo WSPiZ im. L. Koźmińskiego w Warszawie, Warszawa.

Zalega T., (2007), Konsumpcja - podstawy teoretyczne, Wydawnictwo Naukowe Wydziału Zarządzania UW, Warszawa.

Zalega T. (2008), Mikroekonomia, Wydawnictwo Naukowe Wydziału Zarządzania UW, Warszawa.

Zalega T. (2009a), Konsumpcja gospodarstw domowych o niepewnych dochodach $w$ ujęciu tradycyjnych $i$ współczesnych teorii konsumpcji, „Studia i Materiały” No. 1-2 (9-10), Wydawnictwo Naukowe Wydziału Zarządzania UW, Warszawa.

Zalega T. (2009b), Modele zachowań konsumentów w teoriach ekonomicznych i marketingowych, MBA, Wydawnictwo Akademii Leona Koźmińskiego, Warszawa.

Zalega T. (2011), Mikroekonomia wspótczesna, Wydawnictwo Naukowe Wydziału Zarządzania UW, Warszawa.

Zalega T. (2012), Konsumpcja. Determinanty, teorie i modele, PWE, Warszawa. 
